\title{
Changes in methylation of genomic DNA from chicken immune organs in response to H5N1 influenza virus infection
}

\author{
Y.H. Zhang ${ }^{1}$, J.L. Meng' ${ }^{1}$, Y. Gao', J.Y. Zhang ${ }^{1}$, S.L. Niu ${ }^{1}$, X.Z. Yu ${ }^{2}$, \\ Y.B. Li ${ }^{3}$, Y.T. Guan ${ }^{3}$, B.X. Sun ${ }^{1}$ and Z.H. Zhao ${ }^{1}$ \\ ${ }^{1}$ College of Animal Science, Jilin University, Changchun, China \\ ${ }^{2}$ College of Agriculture, Forestry and Life Sciences, Clemson University, \\ Clemson, SC, USA \\ ${ }^{3}$ The Harbin Veterinary Research Institute, \\ Chinese Academy of Agricultural Sciences, Harbin, China \\ Corresponding authors: B.X. Sun / Z.H. Zhao \\ E-mail: sunpathing@sohu.com / zhzhao@jlu.edu.cn
}

Genet. Mol. Res. 15 (3): gmr.15037382

Received January 4, 2016

Accepted August 4, 2016

Published September 16, 2016

DOI http://dx.doi.org/10.4238/gmr.15037382

Copyright (C) 2016 The Authors. This is an open-access article distributed under the terms of the Creative Commons Attribution ShareAlike (CC BY-SA) 4.0 License.

\begin{abstract}
DNA methylation is an important epigenetic modification in eukaryotes, which plays a significant role in regulating gene expression. When the host is invaded by the influenza virus, gene expression is regulated via changes in DNA methylation levels or patterns, leading to the activation or suppression of relevant signaling pathways or networks, triggering a series of immune responses against viral invasion. Here, we investigated the changes in genomic DNA methylation in the immune organs of chicken infected with H5N1 influenza virus. Genome-wide DNA methylation levels in the spleen, thymus, and bursa of Fabricius of specific pathogen-free (SPF) chicken infected with the Guangdong (G-H5N1) and Anhui (A-H5N1) H5N1
\end{abstract}


strains, and water (control) were analyzed by fluorescence-labeled methylation-sensitive amplified polymorphism (F-MSAP). The results indicated that total DNA methylation levels did not differ between spleen genomic DNA in chicken treated with different viral strains and the control $(\mathrm{P}>0.05)$. However, the total DNA methylation levels were significantly upregulated in the thymus $(\mathrm{P}<0.01)$ and bursa $(\mathrm{P}<0.05)$ of chicken in the A-H5N1 group compared to those in the G-H5N1 and control groups. These results provide a basis for the screening of avian influenza-resistance genes or methylation markers, analyzing the epigenetic regulation mechanisms of avian influenza, and performing selective breeding for disease resistance.

Key words: Avian influenza; H5N1; Immune organs; DNA methylation; F-MSAP

\section{INTRODUCTION}

Regulation of gene expression in eukaryotes is achieved as a result of synergy between the genomic, transcriptional, post-transcriptional, translational, and post-translational levels (Meikar et al., 2013; Holoch and Moazed, 2015; Lomniczi et al., 2015; Schübeler, 2015). DNA methylation, which occurs after DNA replication and before transcription, is one of the methods with which the gene is accurately regulated. The DNA methylation process, wherein S-thio-adenosylmethionine serves as a methyl donor and the methyl group is transferred to the fifth carbon atom of cytosine, is catalyzed by DNA methyltransferase (Auclair and Weber, 2012). DNA methylation plays an important role in X chromosome inactivation (Mohandas et al., 1981; Cotton et al., 2015), genetic imprinting (Li et al., 1993; Denomme and Mann, 2013), transposon silencing (Law and Jacobsen, 2010), cell differentiation (Meissner et al., 2008; Bock et al., 2012; Smith and Meissner, 2013; Kulis et al., 2015), maintenance of chromatin structure (Razin, 1998), embryonic development (Anifandis et al., 2015; Aoshima et al., 2015), cancer genesis (Kulis et al., 2013; Paska and Hudler, 2015), among other processes.

DNA methylation affects gene expression by regulating transcription initiation. Essentially, DNA methylation involves the establishment and maintenance of methylation and removal of methyl groups, processes that are catalyzed by corresponding enzymes. A gene that must be "silenced" is immediately methylated resulting in reduced or lack of expression; however, the silenced gene can be re-activated by demethylation, which in turn restores its transcriptional activity. DNA methylation occurs at the cytosine residues of $\mathrm{CpG}$ islands, commonly located in the promoter or first exon region of the gene. Gene expression is negatively correlated with promoter hypermethylation, but is positively or weak-negatively correlated with methylation within the gene (Li et al., 2012; Huang et al., 2014; Hsieh, 2015). Methylation of the cytosine residues at the $\mathrm{CpG}$ islands leads to a change in the binding of transcription factors or the chromatin structure, which causes inhibition of gene transcription, thereby regulating the gene expression and participating in a series of life events (Weber et al., 2005).

Avian influenza virus (AIV) belongs to the influenza type A virus family, which infects vertebrates. There are several subtypes of highly pathogenic AIV (HPAIV), including subtypes $\mathrm{H} 5$ and H7. Ten H5N1 HPAIV clades have been isolated and identified (WHO/OIE/FAO H5N1 Evolution Working Group, 2008). When H5N1 infections are prevalent, the AIV genome may

Genetics and Molecular Research 15 (3): gmr.15037382 
undergo mutations and integrate with other viruses in the host cells, readily resulting in the formation of new antigenic epitopes. As a result, previously developed vaccines could fail to act, resulting in disease development and substantial economic loss to the poultry industry. Additionally, H5N1 AIV alters the antigenic determinants, thereby expanding the scope of potential hosts, posing serious threats to the health of humans and other animals.

At present, research into H5N1 AIV is mainly focused on the pathogenesis, virulence, and prevalence and development of vaccines against the disease (Alkhamis et al., 2015). Few studies have attempted to investigate the regulation of relevant gene expression in the host during AIV infection, through changes in DNA methylation, in order to resist the viral invasion. The results of this study will provide a new perspective towards understanding the epigenetic regulatory mechanism of avian influenza and exploring functional genes that determine resistance traits and their patterns of regulation. This study will also provide a basis for future study in breeding for disease resistance.

\section{MATERIAL AND METHODS}

\section{Ethics statement}

Animal experiments were performed in accordance with the guidelines on animal care established by the Harbin Veterinary Research Institute, Chinese Academy of Agricultural Sciences.

\section{Animals and strains}

BWEL-SPF chicken and subtypes of the H5N1 AIV strains, including the Guangdong strain (A/Goose/Guangdong/1/96, H5N1; G-H5N1) and Anhui strain (A/Duck/Anhui/1/2006, H5N1; A-H5N1), were provided by the Harbin Veterinary Research Institute, Chinese Academy of Agricultural Sciences.

\section{Inoculation}

AIV inoculations were carried out in the P3 laboratory of the Harbin Veterinary Research Institute, Chinese Academy of Agricultural Sciences. Fifteen 4-week-old BWELSPF chicken were randomly divided into three groups ( $\mathrm{N}=5$ per group). The chicken received $10^{6} \mathrm{EID}_{50}\left(50 \%\right.$ egg infectious dose) G-H5N1, A-H5N1, or $\mathrm{ddH}_{2} \mathrm{O}$ per $0.1 \mathrm{~mL}$, using nose drops. The spleen, thymus, and bursa of Fabricius were collected from the chicken in the P3 laboratory 10 days after inoculation.

\section{Genomic DNA extraction and purification}

Genomic DNA (gDNA) was extracted according to the method described by Yang et al. (2011). The extracted gDNA was purified using the MicroElute DNA Clean-Up Kit (Omega, Hartford, CT, USA) according to the manufacturer protocols.

\section{Enzyme digestion}

gDNA purified from the same type of tissue of different individuals in the same group

Genetics and Molecular Research 15 (3): gmr.15037382 
were pooled. Each DNA pool was simultaneously subjected to an enzymatic digestion reaction using $E c o \mathrm{RI}+M s p \mathrm{I}$ and $E c o \mathrm{RI}+H p a \mathrm{II}$. The reaction mixtures were comprised of $4.0 \mu \mathrm{L}$ gDNA $(500 \mathrm{ng} / \mu \mathrm{L}), 10 \mathrm{U}$ EcoRI, $10 \mathrm{U}$ HpaII/MspI, $4.0 \mu \mathrm{L} 10 \mathrm{X}$ Tango ${ }^{\mathrm{TM}}$ buffer, and $12.0 \mu \mathrm{L}$ $\mathrm{ddH}_{2} \mathrm{O}$. The samples were digested at $37^{\circ} \mathrm{C}$ for $12 \mathrm{~h}$.

\section{Enzyme ligation}

The digested products were ligated with $2.0 \mu \mathrm{L} 10 \mathrm{X}$ buffer, 5 pmol EcoRI adapter, $50 \mathrm{pmol} H \mathrm{HpaII}-\mathrm{MspI}$ adapter, and $1.0 \mathrm{U}$ T4 ligase at $37^{\circ} \mathrm{C}$ for $12 \mathrm{~h}$. The adapters and primers for EcoRI and HpaII/MspI were previously described by Yang et al. (2011), with some modifications (Table 1).

Table 1. Adapter and primer sequences used for F-MASP analysis.

\begin{tabular}{|c|c|}
\hline Primers/adapters & Sequence (5'-3') \\
\hline \multirow[t]{2}{*}{ EcoRI adapter } & 5'-CTCGTAGACTCGTACC-3' \\
\hline & 3'-CATCTGAGCATGGTTAA-5' \\
\hline \multirow[t]{2}{*}{ HpaII/MspI adapter } & 5'-GACGATGAGTCTAGAA-3' \\
\hline & 3'-CTACTCAGATCTTGC-5' \\
\hline $\mathrm{E}+1$ primers $(\operatorname{PreAmp})$ & 5'-GACTGCGTACCAATTC+A-3' \\
\hline $\mathrm{HM}+1$ primers $(\operatorname{PreAmp})$ & 5'-GATGAGTCTAGAACGG+T-3' \\
\hline \multirow[t]{8}{*}{$\mathrm{E}+2$ primers } & 5'-GACTGCGTACCAATTC+AAC-3' \\
\hline & 5'-GACTGCGTACCAATTC+AAG-3' \\
\hline & 5'-GACTGCGTACCAATTC+ACG-3' \\
\hline & 5'-GACTGCGTACCAATTC+AGT-3' \\
\hline & 5'-GACTGCGTACCAATTC+ATC-3' \\
\hline & 5'-GACTGCGTACCAATTC+ACT-3' \\
\hline & 5'-GACTGCGTACCAATTC+AGA-3' \\
\hline & 5'-GACTGCGTACCAATTC+ATA-3' \\
\hline \multirow[t]{2}{*}{$\mathrm{HM}+2$ primers } & 5'-FAM ${ }^{1}$-GATGAGTCTAGAACGG+TAC-3' \\
\hline & 5'-FAM -GATGAGTCTAGAACGG+TAG-3' \\
\hline
\end{tabular}

${ }^{1}$ Primer was labeled with the blue fluorescent dye 5-FAM (5-carboxyfluorescein).

\section{Pre-amplification}

The ligation products diluted 16-fold functioned as the template for pre-amplification; $\mathrm{E}+1$ and $\mathrm{HM}+1$ were used as the primers for this reaction (Table 1). The reaction conditions were set as follows: $94^{\circ} \mathrm{C}$ for $5 \mathrm{~min}$; followed by 30 cycles of $94^{\circ} \mathrm{C}$ for $30 \mathrm{~s}, 56^{\circ} \mathrm{C}$ for $1 \mathrm{~min}$, and $72^{\circ} \mathrm{C}$ for $1 \mathrm{~min}$; and a final extension at $72^{\circ} \mathrm{C}$ for $7 \mathrm{~min}$.

\section{Selective amplification}

For selective amplification, pre-amplification products diluted 10 -fold were used as the template; $\mathrm{E}+2$ and FAM-labeled $\mathrm{HM}+2$ primers (16 pairs of primers were obtained using different combinations of $2 \mathrm{HM}+2$ primers and $8 \mathrm{E}+2$ primers; Table 1) were used. The reaction conditions were set as follows: denaturation at $94^{\circ} \mathrm{C}$ for $5 \mathrm{~min}$; 13 cycles of denaturation at $94^{\circ} \mathrm{C}$ for $30 \mathrm{~s}$, annealing at $65^{\circ} \mathrm{C}$ (with a decrement of $0.7^{\circ} \mathrm{C}$ after each cycle) for $30 \mathrm{~s}$, and extension at $72^{\circ} \mathrm{C}$ for $1 \mathrm{~min} ; 23$ cycles at $94^{\circ} \mathrm{C}$ for $30 \mathrm{~s}, 56^{\circ} \mathrm{C}$ for $30 \mathrm{~s}$, and $72^{\circ} \mathrm{C}$ for $1 \mathrm{~min}$; and a final extension at $72^{\circ} \mathrm{C}$ for $10 \mathrm{~min}$.

Genetics and Molecular Research 15 (3): gmr.15037382 
The products of selective amplification were electrophoresed on a $2.0 \%$ agarose gel. DNA methylation polymorphism was analyzed using an ABI377 sequencer (American Applied Biosystems, Foster City, CA, USA).

\section{Statistical analysis}

gDNA methylation levels within the immune organs of different groups of chicken were statistically analyzed using SPSS 16.0 (IBM, Armonk, NY, USA). The significance of the observed differences was examined using one-way analysis of variance (ANOVA), followed by the Duncan LSD test.

\section{RESULTS}

\section{gDNA digestion}

HpaII and MspI are a pair of isoschizomers with the same recognition site, CCGG. However, these two enzymes exhibit different levels of sensitivity to cytosine methylation in the genome (Table 2). HpaII cannot cut the CCGG site when the second cytosine is methylated (full methylation), while $M s p$ I cannot cut the CCGG site when the first cytosine is methylated (hemimethylation). Therefore, the fluorescence-labeled methylation-sensitive amplified polymorphism (F-MSAP) technique detects different digestion patterns in the genome to identify gDNA methylation, ultimately reflecting the methylation levels and patterns of CCGG sites in the genome.

\section{Table 2. Methylation sensitivity and restriction patterns of the HpaII and MspI isoschizomers.}

\begin{tabular}{l|c|c|c|c}
\hline \multirow{2}{*}{ Methylation status } & \multicolumn{4}{|c}{ Enzyme sensitivity } \\
\cline { 2 - 5 } & HpaII & MspI & H & + \\
\hline GGGGCEGG & Active & Active & + & \\
\hline CCGG & Active & Inactive & - \\
\hline GGCC $\underline{\text { CGG }}$ & Inactive & Active & - & + \\
GGC & & & \\
\hline
\end{tabular}

$\mathrm{H}$ and $\mathrm{M}$ indicate the enzyme combinations of EcoRI/HpaII and EcoRI/MspI, respectively; -: band absent; +: band present. Underlined: methylated cytosine.

The digestion results of gDNA are shown in Figure 1. The smear was relatively uniform, without obvious single fragments, indicating that the digestion was sufficient.

\section{Pre-amplification}

The results of pre-amplification are presented in Figure 2. The smear was relatively uniform in the lanes, and the majority of DNA fragments were smaller than $1500 \mathrm{bp}$ in size; however, a few pre-amplification products exceeded $2000 \mathrm{bp}$ in length. 


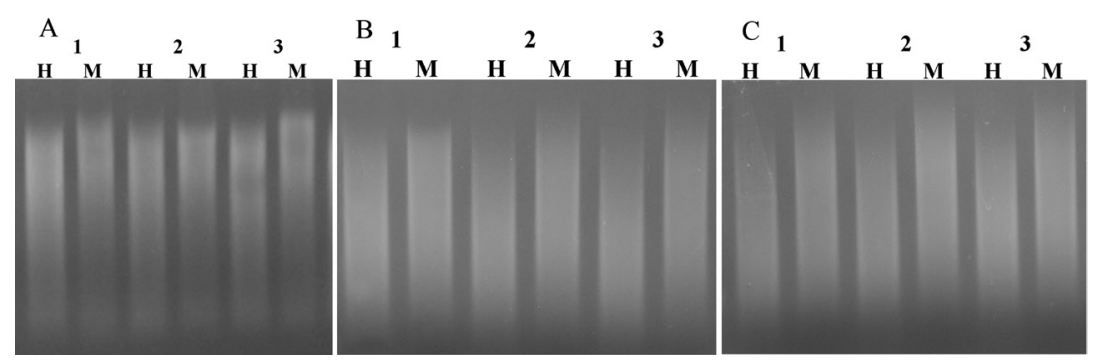

Figure 1. Agarose gel electrophoresis of digested gDNA from spleen, thymus, and bursa of Fabricius. A. B. and C. Electrophoretic images of the chicken spleen, thymus, and bursa of Fabricius, respectively; lanes 1, 2, and 3 represent the A-H5N1, G-H5N1, and control groups. H and M refer to digestion with EcoRI/HpaII and EcoRI/ MspI, respectively.
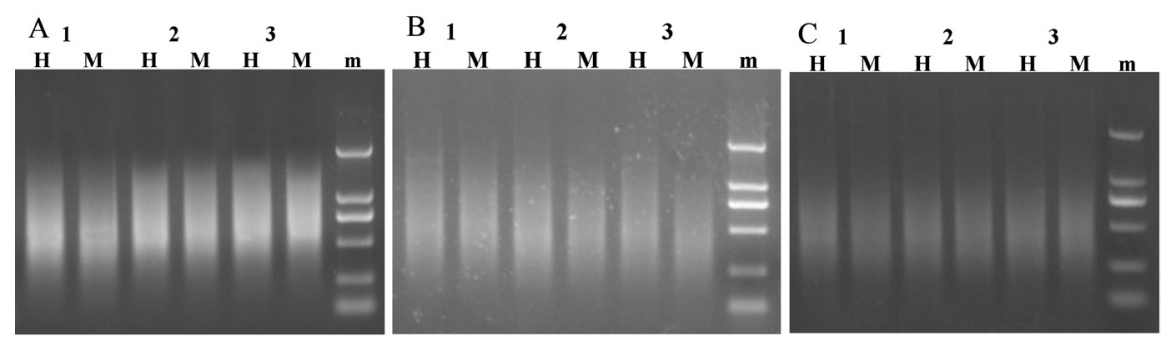

Figure 2. Agarose gel electrophoresis of pre-amplification products of the spleen, thymus, and bursa of Fabricius. A. B. and C. Electrophoretic images of the chicken spleen, thymus, and bursa of Fabricius, respectively; lanes 1, 2, and 3 represent the A-H5N1, G-H5N1, and control groups. H and M refer to digestion with EcoRI/HpaII and EcoRI/MspI. Lane m: DNA DL2000 marker.

\section{Selective amplification}

The results of selective amplification are illustrated in Figure 3. The fragments were diverse and clear, mostly ranging from 100 to $500 \mathrm{bp}$, indicating the efficient of amplification, without the loss of DNA fragments.
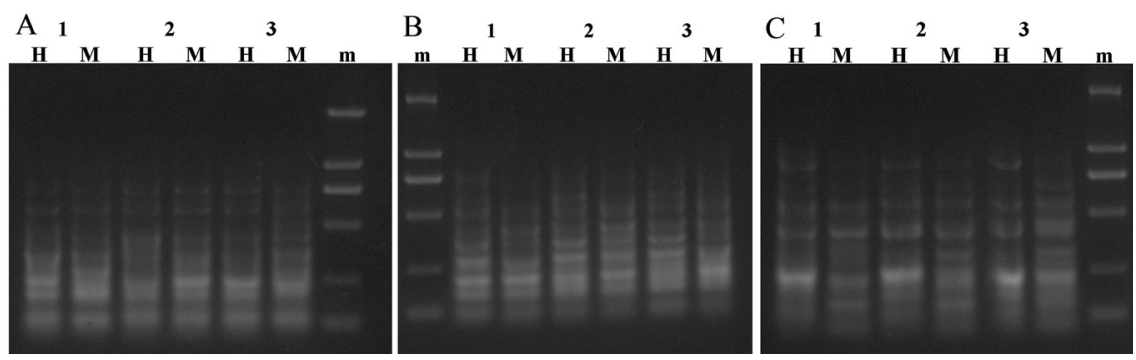

Figure 3. Agarose gel electrophoresis of selective amplification products of the spleen, thymus, and bursa of Fabricius. A. B. and C. Electrophoretic images of the chicken spleen, thymus, and bursa of Fabricius, respectively; lanes 1, 2, and 3 represent the A-H5N1, G-H5N1, and control groups. $\mathrm{H}$ and M refer to digestion with EcoRI/HpaII and EcoRI/MspI. Lane m: DNA DL2000 marker. 


\section{F-MSAP results}

The products of selective amplification with the 16 pairs of fluorescently labeled primers were subjected to electrophoresis using an ABI377 sequencer to obtain fluorescence spectra illustrated in Figure 4.

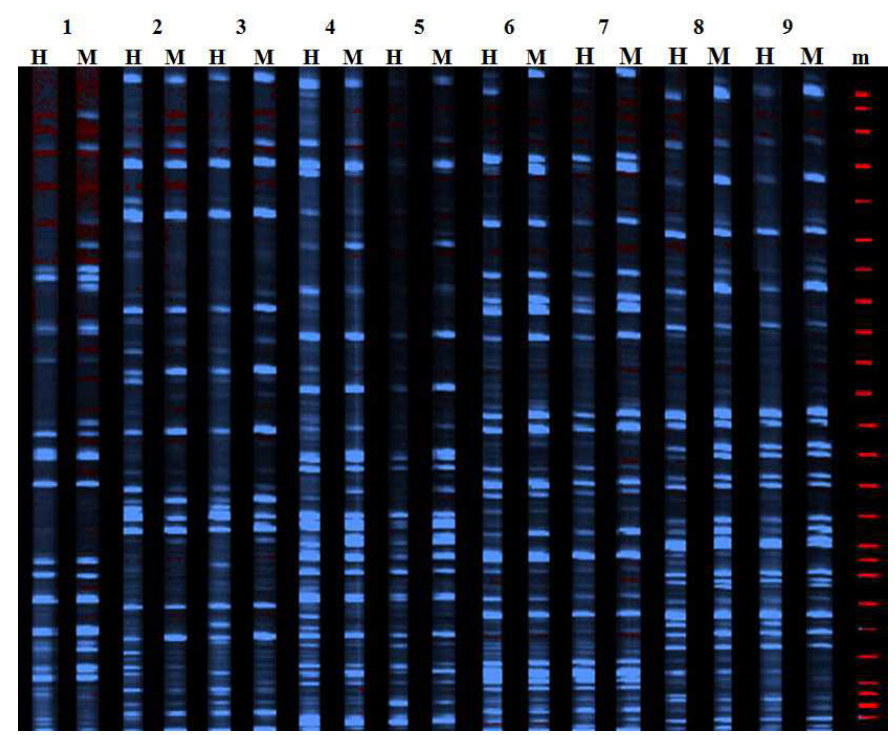

Figure 4. F-MSAP methylation profiles of gDNA from immune organs. Lanes 1-3, 4-6, and 7-9 represent the F-MSAP profiles of the chicken spleen, thymus, and bursa of Fabricius, obtained using the primer combinations $\mathrm{H}-\mathrm{M}+\mathrm{TAG}$ and E+AAC. Lanes 1, 4, and 7 represent the A-H5N1 group; lanes 2, 5, and 8 represent the G-H5N1 group; and lanes 3, 6, and 9 represent the control group. $\mathrm{H}$ and $\mathrm{M}$ refer to digestion with EcoRI/HpaII and EcoRI/ MspI. Lane m: GeneScanTM-500ROXTM size standard.

\section{Statistics for the F-MSAP data}

The obtained fluorescence spectra indicate that the lanes were first corrected using GENESCAN $^{\mathrm{TM}}$ 3.0, with an internal control. Subsequently, the size and location of DNA fragments were determined based on the fluorescence signals detected in the lanes using GeneScan ${ }^{\mathrm{TM}}-500 \mathrm{ROX}^{\mathrm{TM}}$, and the data converted to an Excel spreadsheet using GENESCAN ${ }^{\mathrm{TM}}$ 3.0. Finally, the raw data were converted to values of 0 and 1 , indicating the absence and presence of an amplified fragment at a specific position, respectively. The statistics for the F-MSAP data from chicken spleen, thymus, and bursa of Fabricius, obtained using 16 pairs of primers, are presented in Tables 3, 4, and 5 .

\section{Differences in gDNA methylation in the spleen, thymus, and bursa of Fabricius of chicken from different groups}

The results of ANOVA of genome-wide DNA methylation levels in the various immune organs of the chicken are shown in Table 6. We observed no significant differences between the total DNA methylation levels in the chicken spleen of different groups $(\mathrm{P}>0.05)$.

Genetics and Molecular Research 15 (3): gmr.15037382 
Table 3. F-MSAP statistical results of the spleen.

\begin{tabular}{|c|c|c|c|c|c|c|c|c|c|c|c|c|c|c|c|c|c|}
\hline \multirow[t]{2}{*}{ Group } & \multirow[t]{2}{*}{ Types } & \multicolumn{16}{|c|}{ Primer number and the corresponding amplified fragment } \\
\hline & & 1 & 2 & 3 & 4 & 5 & 6 & 7 & 8 & 9 & 10 & 11 & 12 & 13 & 14 & 15 & 16 \\
\hline \multirow[t]{4}{*}{ SPF } & Full-methylated bands & 23 & 19 & 20 & 23 & 19 & 11 & 10 & 16 & 27 & 21 & 22 & 18 & 18 & 17 & 12 & 7 \\
\hline & Hemimethylated bands & 22 & 13 & 23 & 25 & 22 & 16 & 21 & 19 & 22 & 21 & 12 & 22 & 15 & 17 & 12 & 13 \\
\hline & Methylated bands & 45 & 42 & 43 & 48 & 41 & 27 & 31 & 35 & 49 & 42 & 34 & 40 & 33 & 34 & 24 & 20 \\
\hline & Unmethylated bands & 25 & 36 & 30 & 28 & 26 & 34 & 33 & 33 & 21 & 25 & 25 & 26 & 29 & 28 & 27 & 33 \\
\hline \multirow[t]{4}{*}{ G-H5N1 } & Full-methylated bands & 26 & 18 & 16 & 21 & 33 & 23 & 14 & 17 & 10 & 21 & 13 & 22 & 19 & 22 & 5 & 8 \\
\hline & Hemimethylated bands & 19 & 19 & 18 & 14 & 13 & 15 & 12 & 17 & 16 & 17 & 24 & 24 & 11 & 26 & 17 & 11 \\
\hline & Methylated bands & 45 & 37 & 34 & 35 & 46 & 38 & 26 & 34 & 26 & 38 & 37 & 46 & 30 & 48 & 22 & 19 \\
\hline & Unmethylated bands & 27 & 37 & 36 & 32 & 19 & 33 & 34 & 26 & 30 & 31 & 24 & 26 & 31 & 31 & 33 & 26 \\
\hline \multirow[t]{4}{*}{ A-H5N1 } & Full-methylated bands & 25 & 12 & 12 & 21 & 19 & 19 & 5 & 21 & 22 & 16 & 10 & 18 & 25 & 25 & 11 & 11 \\
\hline & Hemimethylated bands & 27 & 13 & 14 & 24 & 21 & 18 & 13 & 32 & 18 & 16 & 20 & 26 & 34 & 20 & 10 & 9 \\
\hline & Methylated bands & 52 & 25 & 26 & 45 & 40 & 37 & 18 & 53 & 40 & 32 & 30 & 44 & 59 & 45 & 21 & 20 \\
\hline & Unmethylated bands & 19 & 29 & 31 & 19 & 19 & 26 & 32 & 19 & 18 & 29 & 26 & 21 & 12 & 22 & 24 & 28 \\
\hline
\end{tabular}

Table 4. F-MSAP statistical results of thymus.

\begin{tabular}{|c|c|c|c|c|c|c|c|c|c|c|c|c|c|c|c|c|c|}
\hline \multirow[t]{2}{*}{ Group } & \multirow[t]{2}{*}{ Types } & \multicolumn{16}{|c|}{ Primer number and the corresponding amplified fragment } \\
\hline & & 1 & 2 & 3 & 4 & 5 & 6 & 7 & 8 & 9 & 10 & 11 & 12 & 13 & 14 & 15 & 16 \\
\hline \multirow[t]{4}{*}{$\overline{\mathrm{SPF}}$} & Full-methylated bands & 27 & 17 & 18 & 11 & 19 & 18 & 18 & 18 & 18 & 19 & 9 & 23 & 16 & 20 & 14 & 11 \\
\hline & Hemimethylated bands & 24 & 9 & 13 & 19 & 18 & 16 & 16 & 22 & 14 & 18 & 14 & 14 & 24 & 28 & 12 & 8 \\
\hline & Methylated bands & 51 & 26 & 31 & 30 & 37 & 34 & 34 & 40 & 32 & 37 & 23 & 37 & 40 & 48 & 26 & 19 \\
\hline & Unmethylated bands & 24 & 37 & 32 & 32 & 34 & 34 & 33 & 29 & 28 & 24 & 24 & 25 & 26 & 24 & 25 & 31 \\
\hline \multirow[t]{4}{*}{ G-H5N1 } & Full-methylated bands & 35 & 10 & 21 & 16 & 10 & 12 & 22 & 13 & 16 & 16 & 10 & 35 & 14 & 15 & 13 & 11 \\
\hline & Hemimethylated bands & 11 & 11 & 21 & 13 & 29 & 10 & 12 & 16 & 17 & 16 & 7 & 34 & 14 & 18 & 8 & 17 \\
\hline & Methylated bands & 46 & 21 & 42 & 29 & 39 & 22 & 34 & 29 & 33 & 32 & 17 & 69 & 28 & 33 & 21 & 28 \\
\hline & Unmethylated bands & 24 & 41 & 28 & 30 & 25 & 33 & 32 & 26 & 34 & 28 & 34 & 11 & 30 & 27 & 29 & 24 \\
\hline \multirow[t]{4}{*}{ A-H5N1 } & Full-methylated bands & 22 & 14 & 16 & 22 & 27 & 15 & 16 & 20 & 16 & 31 & 18 & 15 & 17 & 32 & 16 & 15 \\
\hline & Hemimethylated bands & 22 & 14 & 11 & 16 & 22 & 17 & 20 & 19 & 16 & 41 & 18 & 17 & 17 & 30 & 16 & 16 \\
\hline & Methylated bands & 44 & 28 & 27 & 38 & 49 & 32 & 36 & 39 & 32 & 72 & 36 & 32 & 34 & 62 & 32 & 31 \\
\hline & Unmethylated bands & 16 & 28 & 28 & 19 & 14 & 21 & 23 & 21 & 23 & 9 & 22 & 18 & 22 & 9 & 20 & 24 \\
\hline
\end{tabular}

Table 5. F-MSAP statistical results of bursa of Fabricius.

\begin{tabular}{|c|c|c|c|c|c|c|c|c|c|c|c|c|c|c|c|c|c|}
\hline \multirow[t]{2}{*}{ Group } & \multirow[t]{2}{*}{ Types } & \multicolumn{16}{|c|}{ Primer number and the corresponding amplified fragment } \\
\hline & & 1 & 2 & 3 & 4 & 5 & 6 & 7 & 8 & 9 & 10 & 11 & 12 & 13 & 14 & 15 & 16 \\
\hline \multirow[t]{4}{*}{ SPF } & Full-methylated bands & 29 & 14 & 13 & 10 & 16 & 13 & 9 & 23 & 19 & 15 & 15 & 18 & 15 & 27 & 12 & 11 \\
\hline & Hemimethylated bands & 23 & 15 & 14 & 17 & 17 & 20 & 14 & 24 & 18 & 16 & 12 & 17 & 13 & 24 & 6 & 11 \\
\hline & Methylated bands & 52 & 29 & 27 & 27 & 33 & 33 & 23 & 47 & 37 & 31 & 27 & 35 & 28 & 51 & 18 & 22 \\
\hline & Unmethylated bands & 22 & 33 & 36 & 34 & 30 & 32 & 36 & 29 & 27 & 31 & 25 & 22 & 26 & 21 & 29 & 35 \\
\hline \multirow[t]{4}{*}{ G-H5N1 } & Full-methylated bands & 21 & 18 & 15 & 20 & 20 & 11 & 14 & 13 & 13 & 6 & 7 & 20 & 10 & 23 & 14 & 8 \\
\hline & Hemimethylated bands & 19 & 12 & 11 & 5 & 20 & 16 & 24 & 18 & 20 & 21 & 13 & 27 & 9 & 17 & 7 & 13 \\
\hline & Methylated bands & 40 & 30 & 26 & 25 & 40 & 27 & 38 & 31 & 33 & 27 & 20 & 47 & 19 & 40 & 21 & 21 \\
\hline & Unmethylated bands & 25 & 34 & 32 & 25 & 25 & 36 & 28 & 31 & 31 & 25 & 31 & 23 & 36 & 28 & 30 & 25 \\
\hline \multirow[t]{4}{*}{ A-H5N1 } & Full-methylated bands & 16 & 11 & 8 & 24 & 20 & 14 & 13 & 9 & 21 & 38 & 20 & 23 & 21 & 16 & 10 & 13 \\
\hline & Hemimethylated bands & 21 & 13 & 12 & 20 & 14 & 11 & 16 & 25 & 24 & 38 & 22 & 22 & 12 & 14 & 11 & 9 \\
\hline & Methylated bands & 37 & 24 & 20 & 44 & 34 & 25 & 29 & 34 & 45 & 76 & 42 & 45 & 33 & 30 & 21 & 22 \\
\hline & Unmethylated bands & 21 & 25 & 32 & 17 & 22 & 24 & 25 & 19 & 20 & 7 & 21 & 17 & 20 & 27 & 24 & 29 \\
\hline
\end{tabular}

Methylated bands $=$ hemimethylated bands + full-methylated bands. $1-16$ represent 16 primer pairs .

However, the total methylation of DNA extracted from the thymus and bursa of Fabricius of chicken in the A-H5N1 group were significantly higher than those seen in the G-H5N1 and control groups $[\mathrm{P}<0.01$ (thymus) and $\mathrm{P}<0.05$ (bursa)].

Genetics and Molecular Research 15 (3): gmr.15037382 
Table 6. Analysis of variance (ANOVA) results of genomic DNA methylation in immune organs.

\begin{tabular}{l|c|c|c|c|c}
\hline \multirow{2}{*}{ Tissues } & \multicolumn{3}{|c|}{ Methylation ratio (\%) } & \multirow{2}{*}{ F values } & \multirow{2}{*}{ P values } \\
\cline { 2 - 5 } & SPF & G-H5N1 & A-H5N1 & & \\
\hline Spleen & $55.89 \pm 2.16$ & $53.49 \pm 2.16$ & $59.56 \pm 3.44$ & 1.325 & 0.276 \\
\hline Thymus & $53.53 \pm 2.07^{\mathrm{a}}$ & $52.20 \pm 3.21^{\mathrm{a}}$ & $65.15 \pm 2.87^{\mathrm{b}}$ & 6.665 & 0.003 \\
\hline Bursa of Fabricius & $51.80 \pm 2.60^{\mathrm{a}}$ & $50.33 \pm 2.27^{\mathrm{a}}$ & $59.80 \pm 3.35^{\mathrm{b}}$ & 3.412 & 0.042 \\
\hline
\end{tabular}

Methylation ratio $=$ methylated bands/total amplified bands; total amplified bands $=$ unmethylated bands + hemimethylated bands + full-methylated bands. Superscript letters mean significant diferrences.

\section{DISCUSSION}

Methylation can be detected using three methods: genome-wide methylation detection, site-specific methylation detection, and identification of new methylation sites. A number of detection methods have been developed over the past decade (Shiraishi et al., 2004; Suzuki and Bird, 2008; Gupta et al., 2010; Mastan et al., 2012; Shan et al., 2012). F-MSAP is a technique used to detect DNA methylation at the whole-genome level. Methylation-sensitive restriction endonucleases do not cut methylated regions; therefore, F-MSAP amplifies the digested gDNA into fragments of different sizes, following which the methylation level and patterns are analyzed. Compared to traditional MSAP, F-MSAP uses fluorescently labeled selective primers, is efficient, sensitive, time-efficient, safe, and automatic (Yang et al., 2011). So far, F-MSAP has been used in biological, medical, and agricultural sciences, among others. In this study, F-MSAP was employed to detect genome-wide DNA methylation levels in the chicken spleen, thymus, and bursa of Fabricius. The methylated fragments detected using 16 pairs of selective primers were diverse, indicating that the F-MSAP detection method is efficient, sensitive, and reliable.

Epigenetics, which includes DNA methylation, histone modifications, and noncoding small RNA, is the study of changes in cellular phenotypes or gene expression, unrelated to changes in the DNA sequences (Sanders et al., 2015). DNA methylation regulates gene expression by two mechanisms: 1$) 5$-methylcytosine $(5 \mathrm{mC})$ methylation affects the interaction between protein factors and DNA. 5mC extends into the major groove of the DNA doublehelix structure, which provides the binding site for a large number of protein factors and contains GC-rich sequences that can be recognized by transcription factors. However, $5 \mathrm{mC}$ methylation leads to the transcription factors being unable to recognize the GC sequences, thereby hindering the binding of specific transcription factors to the recognition site, further affecting the binding of transcription factors to the promoter region. 2) DNA methylation affects the structure of chromatin and alters its conformation. DNA methylation can cause changes in the chromatin structure in the corresponding region, causing the chromatin to become highly spiraled and condensed into clusters. As a result, the DNA endonuclease restriction sites and DNA enzyme-sensitive sites disappear, leading to loss of transcriptional activity and ultimately inhibiting gene expression.

In terms of structure and function, the vertebrate immune system can be divided into innate and adaptive immunity; adaptive defense includes humoral and cellular immunity (Jeurissen et al., 2000). Humoral immunity is responsible for generating specific antibodies, while cellular immunity is involved in cell-mediated cytotoxic reactions and delayed-type hypersensitivity reactions. The avian spleen, thymus, and bursa of Fabricius are extensively involved in both types of immune processes. Methylation of DNA does not alter its primary structure but regulates tissue-specific gene expression by affecting gene transcription and the

Genetics and Molecular Research 15 (3): gmr.15037382 
chromosomal configuration. In other words, gene expression is promoted by maintaining a state of non-methylation, demethylation, or hypomethylation, and conversely, gene expression is inhibited by methylation or by maintaining a hypermethylated state, thereby regulating gene function. A number of life processes (e.g., cell differentiation, embryonic development, $\mathrm{X}$ chromosome inactivation, and disease genesis) are regulated by the synergy between methylation and demethylation. Therefore, when the host is invaded by the H5N1 influenza virus, the body regulates associated gene expression through changes in DNA methylation levels or patterns, thereby activating or blocking a series of signaling pathways or networks related to humoral and cellular immunity, further triggering immune responses to resist the virus. Mukherjee et al. (2013) investigated the DNA methylation of promoter regions in 24 genes regulating inflammation or inflammation-related processes in human lung epithelial cells infected with 4 different AIV strains. Significant methylation differences were detected in the promoter regions of 7 genes; moreover, DNA methylation levels were altered to different degrees after infection with different strains (Mukherjee et al., 2013). Malodobra-Mazur et al. (2014) studied the regulatory activity of stearoyl-CoA desaturase in 22 genes involved in the inflammatory response in 3T3-L1 adipocytes, and reported that the overexpression or silencing of stearoyl-CoA desaturase 1 led to changes in the methylation of inflammatory genes, in turn causing changes in the related genes. In this study, the DNA methylation levels were altered in various immune organs following $\mathrm{H} 5 \mathrm{~N} 1$ infection, indicating that DNA methylation is involved in the regulation of gene expression in avian influenza. Additionally, the DNA methylation levels differed in particular immune organs infected with different H5N1 strains. Such differences might be related to the polymorphisms between different H5N1 subtypes, with amino acid drift presumably resulting in changes in virulence and pathogenicity.

Meanwhile, specific methylated fragments identified in the F-MSAP analysis of different groups were cloned, sequenced, and analyzed. We identified genes related to cell growth and differentiation (receptor tyrosine protein phosphatase), aging (aging-related nuclear prelamin A recognition factor), metabolic balance, hormone regulation and secretion (type I iodothyronine deiodinase), and transcriptional regulation (RNA-binding protein), in addition to genes associated with disease genesis. This finding indicates that interference from external factors results in the initiation or blocking of a series of reactions via changes in DNA methylation levels, thereby maintaining the body balance.

The trait or phenotype is a result of the interaction between genes and the environment (Church, 2011; Womack et al., 2012; McManus et al., 2014). Similarly, disease resistance is regulated by resistance genes (Kaiser, 2010), and individuals in the same environment exhibit varying degrees of resistance to diseases (either susceptible or resistant). There are three types of resistance genes: 1) single major genes, which control the expression of resistance traits; 2) polygenes (minor genes), which individually exert minor effects, with the trait being expressed upon joint action of multiple-minor genes; and 3) independent polygenes, which exist in smaller numbers and exert greater distinguishable individual effects. So far, few studies have analyzed the resistance genes in poultry. DNA methylation regulates the expression of resistance genes, thereby affecting the resistance of the individual to disease. Thus, a comparative analysis of differentially methylated genes between different $\mathrm{H} 5 \mathrm{~N} 1$ infection and control groups could help screen for resistance genes against avian influenza, or methylation markers for marker-assisted selection; this, in turn, could improve the efficiency and accuracy of stock selection, providing a reference for resistance breeding against avian influenza.

Genetics and Molecular Research 15 (3): gmr.15037382 


\section{Conflicts of interest}

The authors declare no conflict of interest.

\section{ACKNOWLEDGMENTS}

Research supported by the Science and Technology Planning Project of Jilin Province (\#20140520167JH) and the National Natural Science Foundation of China (\#30972085). We also appreciate and gratefully acknowledge the Harbin Veterinary Research Institute, Chinese Academy of Agricultural Sciences, for the H5N1 AIV strains and the use of the P3 laboratory.

\section{REFERENCES}

Alkhamis MA, Moore BR and Perez AM (2015). Phylodynamics of H5N1 highly pathogenic avian influenza in Europe, 2005-2010: potential for molecular surveillance of new outbreaks. Viruses 7: 3310-3328. http://dx.doi.org/10.3390/ $\underline{\mathrm{v} 7062773}$

Anifandis G, Messini CI, Dafopoulos K and Messinis IE (2015). Genes and conditions controlling mammalian pre- and post-implantation embryo development. Curr. Genomics 16: 32-46. http://dx.doi.org/10.2174/13892029166661412 $\underline{24205025}$

Aoshima K, Inoue E, Sawa H and Okada Y (2015). Paternal H3K4 methylation is required for minor zygotic gene activation and early mouse embryonic development. EMBO Rep. 16: 803-812.http://dx.doi.org/10.15252/embr.201439700

Auclair G and Weber M (2012). Mechanisms of DNA methylation and demethylation in mammals. Biochimie 94: 22022211. http://dx.doi.org/10.1016/j.biochi.2012.05.016

Bock C, Beerman I, Lien WH, Smith ZD, et al. (2012). DNA methylation dynamics during in vivo differentiation of blood and skin stem cells. Mol. Cell 47: 633-647.http://dx.doi.org/10.1016/j.molcel.2012.06.019

Church GM (2011). New technologies for integrating genomic, environmental and trait data. J. Clin. Sleep Med. 7 (Suppl): S43-S44.

Cotton AM, Price EM, Jones MJ, Balaton BP, et al. (2015). Landscape of DNA methylation on the X chromosome reflects $\mathrm{CpG}$ density, functional chromatin state and X-chromosome inactivation. Hum. Mol. Genet. 24: 1528-1539. http:// dx.doi.org/10.1093/hmg/ddu564

Denomme MM and Mann MR (2013). Maternal control of genomic imprint maintenance. Reprod. Biomed. Online 27: 629-636. http://dx.doi.org/10.1016/j.rbmo.2013.06.004

Gupta R, Nagarajan A and Wajapeyee N (2010). Advances in genome-wide DNA methylation analysis. Biotechniques 49: iii-xi.http://dx.doi.org/10.2144/000113493

Holoch D and Moazed D (2015). RNA-mediated epigenetic regulation of gene expression. Nat. Rev. Genet. 16: 71-84. http://dx.doi.org/10.1038/nrg3863

Hsieh TF (2015). Whole-genome DNA methylation profiling with nucleotide resolution. Methods Mol. Biol. 1284: 27-40. http://dx.doi.org/10.1007/978-1-4939-2444-8_2

Huang YZ, Zhan ZY, Sun YJ, Cao XK, et al. (2014). Intragenic DNA methylation status down-regulates bovine IGF2 gene expression in different developmental stages. Gene 534: 356-361. http://dx.doi.org/10.1016/j.gene.2013.09.111

Jeurissen SH, Boonstra-Blom AG, Al-Garib SO, Hartog L, et al. (2000). Defence mechanisms against viral infection in poultry: a review. Vet. Q. 22: 204-208. http://dx.doi.org/10.1080/01652176.2000.9695059

Kaiser P (2010). Advances in avian immunology - prospects for disease control: a review. Avian Pathol. 39: 309-324.

Kulis M, Queirós AC, Beekman R and Martín-Subero JI (2013). Intragenic DNA methylation in transcriptional regulation, normal differentiation and cancer. Biochim. Biophys. Acta 1829: 1161-1174. http://dx.doi.org/10.1016/j. bbagrm.2013.08.001

Kulis M, Merkel A, Heath S, Queirós AC, et al. (2015). Whole-genome fingerprint of the DNA methylome during human B cell differentiation. Nat. Genet. 47: 746-756. http://dx.doi.org/10.1038/ng.3291

Law JA and Jacobsen SE (2010). Establishing, maintaining and modifying DNA methylation patterns in plants and animals. Nat. Rev. Genet. 11: 204-220. http://dx.doi.org/10.1038/nrg2719

Li E, Beard C and Jaenisch R (1993). Role for DNA methylation in genomic imprinting. Nature 366: 362-365. http:// dx.doi.org/10.1038/366362a0

Li M, Wu H, Luo Z, Xia Y, et al. (2012). An atlas of DNA methylomes in porcine adipose and muscle tissues. Nat. Commun. 3: 850 .http://dx.doi.org/10.1038/ncomms1854

Genetics and Molecular Research 15 (3): gmr.15037382 
Lomniczi A, Wright H and Ojeda SR (2015). Epigenetic regulation of female puberty. Front. Neuroendocrinol. 36: 90-107. http://dx.doi.org/10.1016/j.yfrne.2014.08.003

Malodobra-Mazur M, Dziewulska A, Kozinski K, Dobrzyn P, et al. (2014). Stearoyl-CoA desaturase regulates inflammatory gene expression by changing DNA methylation level in $3 \mathrm{~T} 3$ adipocytes. Int. J. Biochem. Cell Biol. 55: 40-50. http:// dx.doi.org/10.1016/j.biocel.2014.08.005

Mastan SG, Rathore MS, Bhatt VD, Yadav P, et al. (2012). Assessment of changes in DNA methylation by methylationsensitive amplification polymorphism in Jatropha curcas L. subjected to salinity stress. Gene 508: 125-129. http:// dx.doi.org/10.1016/j.gene.2012.07.063

McManus C, do Prado Paim T, de Melo CB, Brasil BS, et al. (2014). Selection methods for resistance to and tolerance of helminths in livestock. Parasite 21: 56. http://dx.doi.org/10.1051/parasite/2014055

Meikar O, Da Ros M and Kotaja N (2013). Epigenetic regulation of male germ cell differentiation. Subcell. Biochem. 61: 119-138. http://dx.doi.org/10.1007/978-94-007-4525-4_6

Meissner A, Mikkelsen TS, Gu H, Wernig M, et al. (2008). Genome-scale DNA methylation maps of pluripotent and differentiated cells. Nature 454: 766-770.

Mohandas T, Sparkes RS and Shapiro LJ (1981). Reactivation of an inactive human X chromosome: evidence for X inactivation by DNA methylation. Science 211: 393-396. http://dx.doi.org/10.1126/science.6164095

Mukherjee S, Vipat VC and Chakrabarti AK (2013). Infection with influenza A viruses causes changes in promoter DNA methylation of inflammatory genes. Influenza Other Respi. Viruses 7: 979-986. http://dx.doi.org/10.1111/irv.12127

Paska AV and Hudler P (2015). Aberrant methylation patterns in cancer: a clinical view. Biochem. Med. 25: 161-176. http:// dx.doi.org/10.11613/BM.2015.017

Razin A (1998). CpG methylation, chromatin structure and gene silencing - a three-way connection. EMBO J. 17: 49054908.http://dx.doi.org/10.1093/emboj/17.17.4905

Sanders YY, Liu H, Liu G and Thannickal VJ (2015). Epigenetic mechanisms regulate NADPH oxidase-4 expression in cellular senescence. Free Radic. Biol. Med. 79: 197-205. http://dx.doi.org/10.1016/j.freeradbiomed.2014.12.008

Schübeler D (2015). Function and information content of DNA methylation. Nature 517: 321-326. http://dx.doi. org/10.1038/nature14192

Shan XH, Li YD, Liu XM, Wu Y, et al. (2012). Comparative analyses of genetic/epigenetic diversities and structures in a wild barley species (Hordeum brevisubulatum) using MSAP, SSAP and AFLP. Genet. Mol. Res. 11: 2749-2759. http://dx.doi.org/10.4238/2012.August.17.2

Shiraishi M, Sekiguchi A, Oates AJ, Terry MJ, et al. (2004). Methyl-CpG binding domain column chromatography as a tool for the analysis of genomic DNA methylation. Anal. Biochem. 329: 1-10.http://dx.doi.org/10.1016/j.ab.2004.02.024

Smith ZD and Meissner A (2013). DNA methylation: roles in mammalian development. Nat. Rev. Genet. 14: 204-220. http://dx.doi.org/10.1038/nrg3354

Suzuki MM and Bird A (2008). DNA methylation landscapes: provocative insights from epigenomics. Nat. Rev. Genet. 9: 465-476. http://dx.doi.org/10.1038/nrg2341

Weber M, Davies JJ, Wittig D, Oakeley EJ, et al. (2005). Chromosome-wide and promoter-specific analyses identify sites of differential DNA methylation in normal and transformed human cells. Nat. Genet. 37: 853-862. http://dx.doi. org/10.1038/ng1598

WHO/OIE/FAO H5N1 Evolution Working Group (2008). Toward a unified nomenclature system for highly pathogenic avian influenza virus (H5N1). Emerg. Infect. Dis. 14: e1.

Womack JE, Jang HJ and Lee MO (2012). Genomics of complex traits. Ann. N. Y. Acad. Sci. 1271: 33-36. http://dx.doi. org/10.1111/j.1749-6632.2012.06733.x

Yang C, Zhang M, Niu W, Yang R, et al. (2011). Analysis of DNA methylation in various swine tissues. PLoS One 6: e16229. http://dx.doi.org/10.1371/journal.pone.0016229

Genetics and Molecular Research 15 (3): gmr.15037382 